\title{
NON-MONETARY INDICATORS OF SOCIAL EXCLUSION - A MULTIDIMENSIONAL COMPARATIVE ANALYSIS OF THE EU-10 COUNTRIES
}

\section{Lukasz Kozar}

University of Lodz, Lodz, Poland

Department of Labour and Social Policy

Faculty of Economics and Sociology

e-mail: lukasz.kozar@uni.lodz.pl

ORCID: 0000-0002-8426-8471

\section{(C) 2021 Łukasz Kozar}

This work is licensed under the Creative Commons Attribution-ShareAlike 4.0 International License. To view a copy of this license, visit http://creativecommons.org/licenses/by-sa/4.0/

Quote as: Kozar, Ł. (2021). Non-monetary indicators of social exclusion - a multidimensional comparative analysis of the EU-10 countries. Econometrics. Ekonometria. Advances in Applied Data Analysis, 25(4).

DOI: 10.15611/eada.2021.4.03

JEL Classification: C43, I32, J64

\begin{abstract}
Social exclusion is a complex and multidimensional process. This phenomenon is also characterised by spatial differentiation, which is illustrated by numerous indicators. Yet, insufficient attention is paid to non-monetary indicators of social exclusion. The aim of this paper was to identify the key non-monetary indicators of social exclusion (also related to the Agenda 2030 sustainable development goals) and, on their basis, to develop a synthetic measure that would make it possible to rank and compare the countries that joined the European Union on May 1, 2004. The considerations were limited to a group of non-monetary indicators of social exclusion selected by the author on the basis of the analysis of the literature on the subject, which included the Laeken indicators. Data on indicator values were taken from the Eurostat database for 2020. In the study, the method of multidimensional comparative analysis of Hellwig's development pattern was used. The analyses showed that, compared to the other countries selected for the analysis, the Czech Republic, Slovenia and Poland were in the most favourable situation in terms of social exclusion understood through the prism of non-monetary indicators.
\end{abstract}

Keywords: social exclusion, sustainable development, multidimensional comparative analysis. 


\section{Introduction}

Social exclusion is an undesirable phenomenon that leads to harmful social consequences manifested in various areas of socio-economic life (Amin, 2019; He, $\mathrm{He}, \mathrm{Zhou}, \mathrm{Nie}, \& \mathrm{He}, 2020)$. In the literature it is discussed quite often together with the issue of poverty (Brzezińska, 2018; Lafuente, Marco, Monfort, \& Ordóñez, 2020; Sulich, Grudziński, \& Kulhánek, 2020). As practice shows, social exclusion, includes various social groups and can occur at any phase of a person's life (Ruesga-Benito, González-Laxe, \& Picatoste, 2018; Seifert, Cotten, \& Xie, 2021). In the author's opinion, social exclusion is one of the factors impeding the transition towards the sustainable development of modern economies. Such a specific phenomenon in the literature is often defined as the impossibility, due to enforced external conditions, of the full participation of individuals as well as entire social groups in socio-economic life (Panek \& Czapiński, 2015; Sobczak, 2016, pp. 10-17). This is not a synthetic definition, nevertheless it draws attention to the multidimensionality of social exclusion. The aspect of multidimensionality, understood as a situation in which individuals become excluded at the same time by a number of different exclusionary factors, is recognized by numerous researchers (Kiat, Cheadle, \& Goosby, 2018; Pellegrini, De Cristofaro, Salvati, Giacomantonio, \& Leone, 2021; Walsh, Scharf, \& Keating, 2017; Ward, 2009).

At the core of social exclusion are exclusionary factors, i.e. factors that prevent full participation in social and economic life. Among them, studies on the subject pay particular attention to the lack of, or limited access, to education and the labour market (Błędowski, Kubicki, 2014; McCluskey, Riddell, Weedon, \& Fordyce, 2016). Disability is also frequently addressed in this area (Goggin, 2016; Wojdyło-Preisner \& Zawadzki, 2015). The aforementioned issues have been the subject of fundamental considerations in the literature for many years in the context of social exclusion (Silver, 1994, 1995, pp. 57-80). However, analyses devoted to the consequences of restricted access to the labour market lead the way here. Thus, actions aimed at counteracting social exclusion and its consequences are often targeted at the professional activation of particular individuals and entire social groups (e.g. by creating preferential employment conditions, or creating special programmes targeted at groups particularly exposed to social exclusion).

Attempts at creating a synthetic definition of social exclusion are also not supported by the fact that this phenomenon is constantly evolving along with the dynamically changing socio-economic reality. The effect of such changes is the widening of the research area that concerns social exclusion. In recent years there has been increasing discussion of, for example, digital exclusion (Ekbia, 2016; Gallistl, Rohner, Seifert, \& Wanka, 2020), exclusion in terms of access to health services (O'Donnell, 2018; Sowa, 2010), and the role of revitalisation in counteracting social exclusion (Przywojska, 2021, 2016, pp. 57-63). The process of continually expanding 
the semantic field of social exclusion undoubtedly contributes to a better and deeper understanding of this phenomenon with its accompanying effects.

For the reasons mentioned above, descriptive explanations rather than synthetic definitions of what social exclusion is, are more common in the literature on the subject. The key feature of all of them is to emphasise that this phenomenon contributes to depriving a given individual or a whole social group of the possibility of full participation in society. Thus, as Giddens points out, social exclusion should be discussed in terms of a certain impairment (2004, p. 347). Such a state can be easily observed in any socio-economic reality, as it results from the limited access of individuals to resources and means. The ability of a given individual to access certain benefits is most often conditioned by his/her social position. This fact is confirmed by the research conducted so far, showing that the principles of goods distribution are based on taking into account social position. Hence it should be stressed that part of society has limited access to certain goods, or is completely deprived of it by the system, and thus is subject to social exclusion (Reimer, 2004). It is therefore impossible to exclude any country from consideration of the spatial impact of this phenomenon.

Social exclusion, due to the effects it may have on socio-economic life, has occupied a particularly important place in the social policy of the European Union since the Lisbon Strategy. However, it took only the financial and economic crisis of 2008 to prove that actions taken on the initiative of both the European Commission and individual EU Member States aimed at counteracting social exclusion are insufficient (Żukowski, 2010). It turned out that one of the key effects of the crisis situation is the intensification of the problem of social exclusion. This fact contributed to raising the status of the issue of social exclusion and placing it among the five key operational objectives of the strategy for 2010-2020, commonly known as the Europe 2020 Strategy (European Commission, 2010). The importance of the issue of social exclusion can also be seen today, for example in the scope of Agenda 2030 (United Nations, 2015), and in the context of the current COVID-19 pandemic (Tsolou, Babalis, \& Tsoli, 2021). Within the scope of the 17 Sustainable Development Goals (SDGs), researchers on the subject see references to issues of social exclusion (Deacon, 2016; Lee, 2020; van Niekerk, 2020).

Taking into account the above presented problems with defining the phenomenon of social exclusion and its effects on the socio-economic environment, for the purpose of this article a general descriptive definition of this concept proposed by Frąckiewicz was adopted, who indicated that it is a multidimensional and dynamic process that accumulates negative phenomena and threats, resulting in the occurrence of multidimensional deprivation (Frąckiewicz, 2005, pp. 11-26). Social exclusion understood in this way formed the basis for a further study whose aim was to compare and rank the countries that joined the European Union on 1 May 2004 (the EU-10: Cyprus, the Czech Republic, Estonia, Hungary, Latvia, Lithuania, Malta, Poland, Slovakia and Slovenia) in regard to selected indicators of social exclusion. The list 
enabled identifying countries in which individuals or entire social groups are particularly exposed to exclusionary factors. In order to achieve this goal, a multidimensional comparative analysis (MCA) was conducted using the method of linear ordering of the Hellwig's development model (Hellwig, 1968, 1990).

This paper is organised as follows. The second section discusses the selection of the diagnostic variables and their transformation process for the survey, and the third section presents the results obtained. The last section contains a discussion and concluding remarks.

\section{The procedure for selecting diagnostic variables for MCA}

\subsection{Selection of social exclusion indicators}

Social exclusion due to its multidimensional nature is defined by a number of monetary and non-monetary indicators (Anand, Jones, Donoghue, \& Teitler, 2021; Kalinowski \& Łuczka-Bakuła, 2005; Panek, 2010). Yet, in the author's opinion, too little emphasis is placed in scientific studies on non-monetary indicators of social exclusion. Their diversity makes it crucial for research aimed at multidimensional comparative analysis to adopt the right criteria for the selection of variables so that they depict this social phenomenon in the fullest possible way. Over the years many researchers have addressed this problem. At this point it is worth mentioning the research conducted by Whelan and Whelan (1995, pp. 38-39), who concluded that social exclusion should be understood in a much broader context than merely through the prism of poverty, unemployment, or the marginalization of people with disabilities. They indicated that important areas that require analysis when considering the phenomenon of social exclusion include education and social participation. Therefore, one should note the increasing attention to the non-monetary issues of social exclusion.

Both a too narrow and too broad a spectrum of indicators taken into account in analysing the phenomenon of social exclusion may adversely affect the results of the conducted analyses (the problem of too narrow inclusion, or conveying the same information through a number of similar variables). In response to this problem, the European Commission proposed a single set of indicators for measuring social exclusion in the EU, which was presented at the Laeken Summit in late 2001 (European Commission, 2003). However, these indicators do not fully reflect the changes in socio-economic life since their introduction. Therefore, for the purpose of conducting the MCA, the author included among the non-monetary indicators from Laeken also those recommended by Eurostat as well as the Social Protection Committee (Atkinson, Guio, \& Marlier, 2017; Social Protection Committee, 2015) when analysing the problem in question, which are at the same time linked to the 2030 Agenda (Table 1). Thanks to this approach, the analyses undertaken refer at the same time to the non-monetary indicators of social exclusion included in the Sustainable Development Goals. 
Table 1. Non-monetary indicators of social exclusion selected for MCA analysis

\begin{tabular}{|c|c|c|c|}
\hline Symbol & Name of the indicator & Description & S/D* \\
\hline $\mathrm{X}_{1} * *$ & $\begin{array}{l}\text { persons living in jobless } \\
\text { households }\end{array}$ & $\begin{array}{l}\text { share of persons aged } 18-59 \text { who are living in } \\
\text { households where no-one works }\end{array}$ & $\mathrm{D}$ \\
\hline $\mathrm{X}_{2} * *$ & $\begin{array}{l}\text { long-term unemployment } \\
\text { rate }\end{array}$ & $\begin{array}{l}\text { number of long-term unemployed (at least } 12 \text { months) } \\
\text { aged } 15-74 \text { as a percentage of the active population of } \\
\text { the same age }\end{array}$ & $\mathrm{D}$ \\
\hline $\mathrm{X}_{3} * *$ & $\begin{array}{l}\text { early school leavers not } \\
\text { in education or training }\end{array}$ & $\begin{array}{l}\text { share of the population aged } 18 \text { to } 24 \text { with at most } \\
\text { lower secondary education (ISCED level } 2 \text { or less) } \\
\text { who were not involved in any education or training } \\
\text { during the four weeks preceding the survey }\end{array}$ & $\mathrm{D}$ \\
\hline $\mathrm{X}_{4} * *$ & life expectancy at birth & $\begin{array}{l}\text { mean number of years that a new-born child can } \\
\text { expect to live if subjected throughout his life to the } \\
\text { current mortality conditions (age specific probabilities } \\
\text { of dying) }\end{array}$ & $S$ \\
\hline $\mathrm{X}_{5} * *$ & $\begin{array}{l}\text { very long-term } \\
\text { unemployment rate }\end{array}$ & $\begin{array}{l}\text { number of very long-term unemployed (at least } 24 \\
\text { months) aged } 15-74 \text { as a percentage of the total active } \\
\text { population of the same age }\end{array}$ & $\mathrm{D}$ \\
\hline $\mathrm{X}_{6} * *$ & $\begin{array}{l}\text { share of long-term } \\
\text { unemployment }\end{array}$ & $\begin{array}{l}\text { number of long-term unemployed (at least } 12 \text { months) } \\
\text { aged } 15-74 \text { as a percentage of the total number of } \\
\text { unemployed of the same age }\end{array}$ & $\mathrm{D}$ \\
\hline $\mathrm{X}_{7}$ & $\begin{array}{l}\text { share of very long-term } \\
\text { unemployment }\end{array}$ & $\begin{array}{l}\text { number of very long-term unemployed (at least } 24 \\
\text { months) aged } 15-74 \text { as a percentage of the total } \\
\text { number of unemployed of the same age }\end{array}$ & $\mathrm{D}$ \\
\hline $\mathrm{X}_{8} * *$ & $\begin{array}{l}\text { persons with low } \\
\text { educational attainment }\end{array}$ & $\begin{array}{l}\text { percentage of the total population of } 25-64 \text { year olds } \\
\text { who have achieved ISCED level } 2 \text { or less (less than } \\
\text { primary, primary and lower secondary education) }\end{array}$ & $\mathrm{D}$ \\
\hline $\mathrm{X}_{9}$ & $\begin{array}{l}\text { self-reported unmet } \\
\text { needs for medical } \\
\text { examination }\end{array}$ & $\begin{array}{l}\text { percentage of the total population of } 16 \text { years or over } \\
\text { who declare unmet medical care needs (reasons: too } \\
\text { expensive or too far to travel or waiting list) }\end{array}$ & $\mathrm{D}$ \\
\hline $\mathrm{X}_{10}$ & $\begin{array}{l}\text { people living in } \\
\text { households with very } \\
\text { low work intensity }\end{array}$ & $\begin{array}{l}\text { share people aged } 0-59 \text { living in households where the } \\
\text { adults work } 20 \% \text { or less of their total work potential } \\
\text { during the past year }\end{array}$ & $\mathrm{D}$ \\
\hline $\mathrm{X}_{11}$ & $\begin{array}{l}\text { young people neither in } \\
\text { employment nor in } \\
\text { education and training } \\
\text { (NEET) }\end{array}$ & $\begin{array}{l}\text { share of the population aged } 15-29 \text { not in } \\
\text { employment, education or training (formal or non- } \\
\text { formal) }\end{array}$ & $\mathrm{D}$ \\
\hline
\end{tabular}

* S - stimulant (the higher the indicator value, the more favourable the examined situation), ** Laeken, indicators, D - destimulant (the higher the indicator value, the more unfavourable the examined situation).

Source: own work based on (Atkinson, Guio, \& Marlier, 2017; European Commission, 2003; Social Protection Committee, 2015).

In order to construct an appropriate set of initial (potential) variables in this study, it was assumed that Eurostat would be the only source of information on the values of particular statistical indicators for the selected EU-10 countries. It should be noted that among the indicators selected and presented in Table 1 it is difficult to find variables 
related to e.g. disability, addictions, membership of national and ethnic minorities, digital exclusion or imprisonment. However, these issues do affect the values of the given social exclusion indicators, so they are included in an indirect way. The data used in the research, due to the criterion of timeliness and availability of data, concern the year 2020. In order to conduct analyses and later on to present them, STATA was used.

From the set of 11 indicators selected during the theoretical analysis, most of them are destimulants (except for indicator $\mathrm{X}_{4}$ ). The data was found to be complete in relation to all analysed EU-10 countries. In the next step of the procedure (1-3), the indicators were subjected to statistical analysis, the aim of which was to determine their discriminatory capacity, i.e. their variability in relation to the analysed objects (Panek, 2009). The classical coefficient of variation was used for this purpose. The analysis undertaken was aimed at obtaining additional information on the selected variables for further interpretative purposes. At this stage the elimination of variables based on the coefficient of variation was abandoned, as in light of contemporary research, such an action was considered inappropriate (Sokołowski \& Markowska, 2017).

$$
V^{k}\left(x_{j}\right)=\frac{s\left(x_{j}\right)}{\bar{x}_{j}} \times 100, j=1,2, \ldots, m,
$$

where: $\bar{x}_{j}-$ the arithmetic mean of the values of the $j$-th variable, whereby:

$$
\bar{x}_{j}=\frac{\sum_{i=1}^{n} x_{i j}}{n},
$$

$S\left(x_{j}\right)$ - the standard deviation of the $j$-th variable, whereby:

$$
S\left(x_{j}\right)=\sqrt{\frac{\sum_{i=1}^{n}\left(x_{i j}-\bar{x}_{j}\right)^{2}}{n-1}} .
$$

In the next step of forming an appropriate set of variables for the MCA, all 11 indicators were subjected to variable capacity assessment, i.e. their information potential was determined. This was necessary due to the fact that the selected nonmonetary indicators could provide information with similar content (similar data aggregation especially in the labour market context). The capacity of the variables was determined by applying Hellwig's parametric method for which a threshold value of correlation coefficient $r^{*}$ was set, i.e. a value above which the variables are assumed to be significantly correlated. The author used here the minimax method:

$$
r^{*}=\min _{j} \max _{j^{\prime}}\left|r_{j j^{\prime}}\right|, j, j^{\prime}=1,2, \ldots, m,
$$

where: $r_{j j^{\prime}}$ - the correlation coefficient between the $j$-th and $j^{\prime}$-th admissible diagnostic variables.

The critical value of the correlation coefficient calculated with the minimax method was 0.437 . The applied parametric Hellwig's method allowed to divide the 
indicators into central variables (representative variables) and corresponding satellite variables (Table 2).

Table 2. Results of Hellwig's parametric method for distinguishing diagnostic variables

\begin{tabular}{|c|c|c|}
\hline Representative variables & Type of variable & Satellite variables to central variables \\
\hline $\mathrm{X}_{5}$ & central variable & $\mathrm{X}_{2}, \mathrm{X}_{6}, \mathrm{X}_{7}$ \\
\hline $\mathrm{X}_{1}$ & central variable & $\mathrm{X}_{4}, \mathrm{X}_{8}, \mathrm{X}_{9}, \mathrm{X}_{10}$ \\
\hline $\mathrm{X}_{11}$ & isolated variable & - \\
\hline $\mathrm{X}_{3}$ & isolated variable & - \\
\hline
\end{tabular}

Source: own work based on (Eurostat, 2021) in STATA.

The coefficients of variation of the indicators selected for the final set of diagnostic variables and the application of Hellwig's parametric method allowed to conclude that the information value of the selected indicators was adequate for conducting a multidimensional comparative analysis.

\subsection{Transformation of the diagnostic variables for the survey}

Before applying the methods of multidimensional comparative analysis on a set of diagnostic variables, their transformation was carried out with the aim of:

- harmonisation of the nature of the variables adopted,

- making the variables mutually comparable,

- replacing the different ranges of variation of individual variables by a fixed range,

- eliminating negative values of the variables thus developed from the calculations.

Carrying out the procedures indicated above is essential for the MCA to be performed correctly (Grabiński, Wydymus, \& Zeliaś, 1989; Panek \& Zwierzchowski, 2013). First, the stimulation of the variables was carried out. It consisted in a differential transformation of destimulants into stimulants:

$$
x_{i j}^{S}=a-b x_{i j}^{D}, \mathrm{i}=1,2, \ldots, n ; j=1,2, \ldots, m ; b>0,
$$

where: $x_{i j}^{S}$ - the value of the $j$-th variable after transformation into a stimulant at the $i$-th object, $x_{i j}^{D}$ - the value of the $j$-th destimulant variable in the $i$-th object, $a$ - fixed to be adopted arbitrarily, in this case $a=0, b$ - fixed to be adopted arbitrarily, in this case $b=1$.

As a result of the stimulation, the set of diagnostic variables was unified in terms of their preferences (all variables fulfilled the following relation - the higher the numerical indicator describing a given variable, the more favourable its value contributed to the assessment of the situation of a given EU-10 country in comparison with other countries in terms of the indicator describing the situation of social exclusion based on non-monetary indicators). 
Then, due to the fact that the variables selected for the study were characterised by different units of measurement, the range of variation was normalised for all four diagnostic variables. For this purpose a normalisation transformation based on classical standardisation was applied:

$$
z_{i j}=\frac{x_{i j}-\bar{x}_{j}}{s\left(x_{j}\right)}, i=1,2, \ldots, n ; j=1,2, \ldots, m,
$$

where: $z_{i j}$ - the normalised value of the $j$-th variable in the $i$-th object.

The normalised variables in the last step of the transformation were subjected to the procedure of eliminating negative values of the variables (7-8). Thanks to constant $\varepsilon$, which caused an upward shift on the scale of the values of all variables by the same amount, the mutual relation between the examined variables was maintained.

$$
z_{i j}=\left\{\begin{array}{c}
z_{i j}, \text { when } \min _{i, j}\left\{z_{i j}\right\}>0, \\
z_{i j}+\varepsilon \text {, when } \min _{i, j}\left\{z_{i j}\right\} \leq 0,
\end{array} i=1,2, \ldots, n ; j=1,2, \ldots, m,\right.
$$

whereby:

$$
\varepsilon=-\min _{i, j}\left\{z_{i j}\right\}+\frac{1}{5} S(z),
$$

where: $S(z)$ - the standard deviation calculated from all elements of the matrix of normalised input data.

The transformation of the diagnostic variables carried out as described above contributed to their adequate standardisation so that they could be subjected to ordering methods at a later stage.

\section{Empirical results}

In the study aimed at comparing the situation of the EU-10 countries in terms of social exclusion on the basis of selected non-monetary indicators, the Hellwig's development pattern was used. The method made it possible to compare the EU-10 countries on the basis of the determined benchmark, which was the most favourable situation that occurred in the scope of particular non-monetary indicators of social exclusion selected in the procedure of their selection for the study. The obtained results are presented in Table 3.

In the ranking of EU-10 countries obtained using Hellwig's method, the first place was taken by the Czech Republic, which means that this country was characterised by a situation in terms of the level of social exclusion closest to the model (a situation that is realistically attainable, and at the same time the least exclusionary). Last place in the presented ranking was taken by Cyprus, while Poland was ranked third in the EU-10 in terms of the situation regarding social exclusion caused by non-monetary factors. 
Table 3. Ranking of the EU-10 countries in terms of their social exclusion situation (non-monetary approach) according to Hellwig's development pattern method for 2020

\begin{tabular}{|l|c|}
\hline \multicolumn{1}{|c|}{ Country } & Value of synthetic variable \\
\hline Czechia & 0.561 \\
\hline Slovenia & 0.504 \\
\hline Poland & 0.450 \\
\hline Malta & 0.397 \\
\hline Estonia & 0.305 \\
\hline Latvia & 0.220 \\
\hline Hungary & 0.219 \\
\hline Lithuania & 0.191 \\
\hline Slovakia & 0.157 \\
\hline Cyprus & 0.117 \\
\hline
\end{tabular}

Source: own work based on (Eurostat, 2021) in STATA.

The results obtained with the MCA were grouped using the standard deviation method. Therefore, the EU-10 countries were divided into four groups (Table 4), containing countries with values of the synthetic variable belonging to the following four class intervals:

$$
\begin{gathered}
\operatorname{Group}_{1}: s_{i}<\bar{s}-S(s), \\
\operatorname{Group}_{2}: \bar{s}>s_{i} \geq s_{i}-S(s), \\
\operatorname{Group}_{3}: \bar{s}+S(s)>s_{i} \geq \bar{s}, \\
\operatorname{Group}_{4}: s_{i} \geq \bar{s}+S(s),
\end{gathered}
$$

where: $\bar{s}, S(s)$ - the arithmetic mean and the standard deviation of the synthetic variable, respectively.

Table 4. Results of grouping the EU-10 countries by standard deviations

\begin{tabular}{|l|c|c|}
\hline \multicolumn{1}{|c|}{ Country } & Value of synthetic variable & Group number \\
\hline Cyprus & 0.117 & 1 \\
\hline Slovakia & 0.157 & \multirow{2}{*}{2} \\
\cline { 1 - 2 } Lithuania & 0.191 & \multirow{2}{*}{2} \\
\hline Hungary & 0.219 & \\
\hline Latvia & 0.220 & \multirow{2}{*}{3} \\
\hline Estonia & 0.305 & \multirow{2}{*}{4} \\
\hline Malta & 0.397 & \\
\hline Poland & 0.450 & \\
\hline Slovenia & 0.504 & \\
\hline Czechia & 0.561 & \\
\hline
\end{tabular}

Source: own work based on (Eurostat, 2021) in STATA. 
The purpose of the grouping presented in Table 4 was to define the situation of a given country in terms of social exclusion (non-monetary approach) more clearly than on the basis of Hellwig's development pattern method. The objects with the best situation in comparison with the others were classified in group 4 which includes the Czech Republic and Slovenia. On the other hand, facilities with the worst situation in comparison with the EU-10 awee in group 1. Based on the method of standard deviations, only Cyprus (the lowest value of the synthetic measure) was classified in this group. In group 3 (with a relatively good level of social exclusion in comparison with the other EU-10), apart from Poland, there was also Malta. The remaining countries were placed in group 2 (relatively unfavourable situation in terms of social exclusion in comparison with group 3 and 4).

\section{Discussion and conclusion}

The study conducted in this article using MCA methods to compare the EU-10 countries among themselves in terms of the social exclusion situation based on nonmonetary variables showed the great importance of selecting the appropriate variables for research. In particular, the importance of the process of selecting diagnostic variables for this type of research was highlighted by Walesiak, Sokołowski and Markowska (e.g. Markowska, Sokolowski, \& Strahl, 2021; Walesiak, 2016). In view of these analyses made, the author observed the indicated aspect, which further stressed the need to pay attention to the informative potential of the variables.

The analyses conducted by the author indicate that currently many different nonmonetary indicators are used to study the issue of social exclusion (used depending on the research context). This aspect was discernible in numerous studies focused on the issues of poverty, quality of life, and social exclusion (e.g. Bárcena-Martín, Pérez-Moreno, \& Rodríguez-Díaz, 2020; Grzebyk \& Stec, 2015; Piwowarski, Miłaszewicz, Łatuszyńska, Borawski, \& Nermend, 2018). These indicators are constantly evolving, with a noticeably increasing shift away from the classical understanding of social exclusion understood through lack of employment. Currently, more and more researchers focus on social exclusion and raise the issue of quality of life (Lee, 2021; Waldegrave \& Phillipson, 2020). The author joins this group in his analyses, for example by taking into account the indicator of self-reported unmet needs for medical examination.

The author's view on social exclusion is based on non-monetary indicators of social exclusion, which also distinguishes the paper from other researchers who most often included in their analyses all indicators of social exclusion, hence also those of monetary nature (e.g. Nolan \& Whelan, 2010). In studies of this type, the author recognises that quite often the set of diagnostic variables ultimately includes no nonmonetary indicators or their representation is marginal. By adding new variables to Laeken's non-monetary indicators of social exclusion, the author was able to look at the phenomenon of social exclusion in a more comprehensive way. It should be noted 
that among the four variables selected for the study proper, there was one indicator proposed by the author based on the analysis of the literature on the subject and at the same time referring to the SDGs (young people neither in employment nor in education and training - NEET). According to the ranking made in the study, compared to the EU-10, a particularly unfavourable situation in terms of social exclusion caused by non-monetary indicators can be observed in Cyprus, Slovakia and Lithuania.

As regards the favourable situation in terms of social exclusion in comparison with the other EU-10 countries, Poland took third position in the ranking obtained. While it is a good result in comparison with other countries, it should be pointed out that at the same time the value of the synthetic variable obtained by Poland is relatively far from the pattern adopted in the study (the situation is still exclusionary, but the most advantageous in comparison with the whole). The analyses carried out may be an important indication in the construction of similar statements in the future, which, in the author's opinion, should be supplemented with new non-monetary indicators within the framework of data availability, bearing in mind the necessity of adequate examination of the information potential of the variables.

\section{References}

Amin, S. (2019). Diversity enforces social exclusion: Does exclusion never cease? Journal of Social Inclusion, 10(1), 4-23.

Anand, P., Jones, S., Donoghue, M., \& Teitler, J. (2021). Non-monetary poverty and deprivation: A capability approach. Journal of European Social Policy, 31(1), 78-91.

Atkinson, A. B., Guio, A-C., \& Marlier, E. (Eds.). (2017). Monitoring social inclusion in Europe. Luxembourg: Publications Office of the European Union.

Bárcena-Martín, E., Pérez-Moreno, S., \& Rodríguez-Díaz, B. (2020). Rethinking multidimensional poverty through a multi-criteria analysis. Economic Modelling, 91, 313-325.

Błędowski, P., \& Kubicki, P. (2014). Lokalna polityka społeczna wobec nowych wyzwań. Od interwencji do aktywizacji. Polityka Spoteczna, (3), 34-38.

Brzezińska, J. (2018). Statistical analysis of economic poverty in Poland using R. Ekonometria, 22(2), 45-53.

Deacon, B. (2016). SDGs, Agenda 2030 and the prospects for transformative social policy and social development. Journal of International and Comparative Social Policy, 32(2), 79-82.

Ekbia, H. R. (2016). Digital inclusion and social exclusion: The political economy of value in a networked world. The Information Society, 32(3), 165-175.

European Commission. (2003). Laeken indicators - detailed calculation methodology. DOC.E2/ IPSE/2003.

European Commission. (2010). Europe 2020. A strategy for smart, sustainable and inclusive growth $\operatorname{COM}(2010) 2020$ final. Retrieved from https://eur-lex.europa.eu/legal-content/EN/ALL/? uri=celex:52010DC2020

Eurostat. (2021). Retrieved from https://ec.europa.eu/eurostat

Frąckiewicz, L. (2005). Wykluczenie społeczne w skali makro- i mikroekonomicznej. In L. Frąckiewicz (Ed.), Wykluczenie spoleczne. Katowice: Wydawnictwo AE w Katowicach.

Gallistl, V., Rohner, R., Seifert, A., \& Wanka, A. (2020). Configuring the older non-user: Between research, policy and practice of digital exclusion. Social Inclusion, 8(2), 233-243. 
Giddens, A. (2004). Socjologia. Warszawa: Wydawnictwo Naukowe PWN.

Goggin, G. (2016). Disability and mobilities: Evening up social futures. Mobilities, 11(4), 533-541.

Grabiński, T., Wydymus, S., \& Zeliaś A. (1989). Metody taksonomii numerycznej w modelowaniu zjawisk społeczno-gospodarczych. Warszawa: Wydawnictwo Naukowe PWN.

Grzebyk, M., \& Stec, M. (2015). Sustainable development in EU countries: Concept and rating of levels of development. Sustainable Development, 23(2), 110-123.

He, J., He, L., Zhou, W., Nie, X., \& He, M. (2020). Discrimination and social exclusion in the outbreak of COVID-19. International Journal of Environmental Research and Public Health, 17(8), 2933.

Hellwig, Z. (1968). Application of the taxonomic method to the typological division of countries according to the level of their development and the resources and structure of qualified personnel. Przeglad Statystyczny, (4), 307-327.

Hellwig, Z. (1990). Taksonometria ekonomiczna, jej osiagnięcia, zadania i cele. In J. Pociecha (Ed.). Taksonomia - teoria i jej zastosowania. Kraków: Akademia Ekonomiczna w Krakowie.

Kalinowski, S., \& Łuczka-Bakuła, W. (2005). Wybrane monetarne wskaźniki społecznego wykluczenia w nowych krajach UE. Polityka Społeczna, (7), 5-8.

Kiat, J. E., Cheadle, J. E., \& Goosby, B. J. (2018). The impact of social exclusion on anticipatory attentional processing. International Journal of Psychophysiology, (123), 48-57.

Lafuente, J. Á., Marco, A., Monfort, M., \& Ordóñez, J. (2020). Social exclusion and convergence in the EU: An assessment of the Europe 2020 strategy. Sustainability, 12(5), 1843.

Lee, S. (2020). Role of social and solidarity economy in localizing the sustainable development goals. International Journal of Sustainable Development \& World Ecology, 27(1), 65-71.

Lee, S. (2021). Social exclusion and subjective well-being among older adults in Europe: Findings from the European Social Survey. The Journals of Gerontology: Series B, 76(2), 425-434.

Markowska, M., Sokolowski, A., \& Strahl, D. (2021). Flexible multidimensional scaling for human smart development analysis in EU Countries. European Research Studies Journal, 4(24), 435-445.

McCluskey, G., Riddell, S., Weedon, E., \& Fordyce, M. (2016). Exclusion from school and recognition of difference. Discourse: Studies in the Cultural Politics of Education, 37(4), 529-539.

Niekerk van, A. J. (2020). Inclusive economic sustainability: SDGs and global inequality. Sustainability, 12(13), 5427.

Nolan, B., \& Whelan, C. T. (2010). Using non-monetary deprivation indicators to analyze poverty and social exclusion: Lessons from Europe? Journal of Policy Analysis and Management, 29(2), 305-325.

O’Donnell, P., O’Donovan, D., \& Elmusharaf, K. (2018). Measuring social exclusion in healthcare settings: a scoping review. International Journal for Equity in Health, 17(1), 1-16.

Panek, E. (2010). Wielowymiarowy obraz ubóstwa w Polsce w ujęciu terytorialnym. Wiadomości Statystyczne. The Polish Statistician, 55(2), 18-37.

Panek, T. (2009). Statystyczne metody wielowymiarowej analizy porównawczej. Warszawa: Szkoła Główna Handlowa w Warszawie - Oficyna Wydawnicza.

Panek, T., \& Czapiński, J. (2015). Wykluczenie społeczne. Contemporary Economics, (4), 396-432.

Panek, T., \& Zwierzchowski, J. (2013). Statystyczne metody wielowymiarowej analizy porównawczej. Teoria i zastosowanie. Warszawa: Szkoła Główna Handlowa w Warszawie - Oficyna Wydawnicza.

Pellegrini, V., De Cristofaro, V., Salvati, M., Giacomantonio, M., \& Leone, L. (2021). Social exclusion and anti-immigration attitudes in Europe: The mediating role of interpersonal trust. Social Indicators Research, 155(2), 697-724.

Piwowarski, M., Miłaszewicz, D., Łatuszyńska, M., Borawski, M., \& Nermend, K. (2018). Application of the vector measure construction method and technique for order preference by similarity ideal solution for the analysis of the dynamics of changes in the poverty levels in the European union countries. Sustainability, 10(8), 2858. 
Przywojska, J. (2016). Rewitalizacja miast. Aspekt społeczny. Łódź: Wydawnictwo Uniwersytetu Łódzkiego.

Przywojska, J. (2021). Polish local government's perspective on revitalisation: A framework for future socially sustainable solutions. Energies, 14(16), 4888.

Reimer, B. (2004). Social exclusion in a comparative context. Sociologia Ruralis, 44(1), 76-94.

Ruesga-Benito, S. M., González-Laxe, F., \& Picatoste, X. (2018). Sustainable development, poverty, and risk of exclusion for young people in the European Union: the case of NEETs. Sustainability, 10(12), 4708.

Seifert, A., Cotten, S. R., \& Xie, B. (2021). A double burden of exclusion? Digital and social exclusion of older adults in times of COVID-19. The Journals of Gerontology: Series B, 76(3), e99-e103.

Silver, H. (1994). Social exclusion and social solidarity: Three paradigms. International Labour Review, (133), 531-578.

Silver, H. (1995). Reconceptualizing social disadvantage: Three paradigms of social exclusion. In G.G. Rodgers, J.B. Figueiredo (Eds.). Social exclusion: Rhetoric, reality, responses. Geneva: Institute of International Labour Studies.

Sobczak, M. (2016). Wykluczenie społeczne i inkluzja społeczna z wykorzystaniem podmiotów ekonomii społecznej w Polsce na przykładzie województwa łódzkiego. Łódź: Wydawnictwo Uniwersytetu Łódzkiego.

Social Protection Committee. (2015). Portfolio of EU social indicators for the monitoring of progress towards the EU objectives for social protection and social inclusion. Luxembourg: Publications Office of the European Union.

Sokołowski, A., \& Markowska, M. (2017). Iteracyjna metoda liniowego porządkowania obiektów wielocechowych. Przegląd Statystyczny, 2(64), 153-162.

Sowa, A. (2010). O nierównościach w korzystaniu z usług ochrony zdrowia ze względu na wykształcenie. Polityka Społeczna, (9), 33-36.

Sulich, A., Grudziński, A., \& Kulhánek, L. (2020). Zielony wzrost gospodarczy-analiza porównawcza Czech i Polski. Prace Naukowe Uniwersytetu Ekonomicznego we Wrocławiu, 64(5), 192-207.

Tsolou, O., Babalis, T., \& Tsoli, K. (2021). The impact of COVID-19 pandemic on education: social exclusion and dropping out of school. Creative Education, 12(3), 529.

United Nations. (2015). Transforming our world: The 2030 agenda for sustainable development. A/RES/70/1. Retrieved from https://www.un.org/ga/search/view_doc.asp?symbol=A/RES/70/ $1 \&$ Lang $=\mathrm{E}$

Waldegrave, C., \& Phillipson, C. (2020). Social exclusion and material disadvantage: Housing, poverty, and living standards impacts. Innovation in Aging, (4), 712-712.

Walesiak, M. (2016). Visualization of linear ordering results for metric data with the application of multidimensional scaling. Ekonometria, 2(52), 9-21.

Walsh, K., Scharf, T., \& Keating, N. (2017). Social exclusion of older persons: A scoping review and conceptual framework. European Journal of Ageing, 14(1), 81-98.

Ward, N. (2009). Social exclusion, social identity and social work: Analysing social exclusion from a material discursive perspective. Social Work Education, 28(3), 237-252.

Whelan, B. J., \& Whelan, C. T. (1995). In what sense is poverty multidimensional? In G. Room, (Ed.). Beyond the threshold: The measurement and analysis of social exclusion. Bristol: Policy Press.

Wojdyło-Preisner, M., \& Zawadzki, K. (2015). Determinanty podejmowania aktywności zawodowej i pracy przez osoby niepełnosprawne. Polityka Społeczna, (7), 29-34.

Żukowski, M. (2010). Unijna strategia integracji społecznej. Polityka Społeczna, (9), 2-7. 


\section{NIEMONETARNE WSKAŹNIKI WYKLUCZENIA SPOLECZNEGO - WIELOWYMIAROWA ANALIZA PORÓWNAWCZA PAŃSTW UE-10}

Streszczenie: Ekskluzja społeczna jest złożonym i wielowymiarowym procesem. Zjawisko to cechuje się również przestrzennym zróżnicowaniem, co obrazują liczne wskaźniki. Wciąż niewystarczającą uwagę poświęca się wskaźnikom niemonetarnym wykluczenia społecznego. Celem niniejszego artykułu jest zatem wskazanie kluczowych niemonetarnych wskaźników wykluczenia społecznego (związanych jednocześnie z celami zrównoważonego rozwoju z Agendy 2030) i na ich podstawie opracowanie miary syntetycznej umożliwiającej uporządkowanie oraz porównanie państw, które wstąpiły do Unii Europejskiej 1 maja 2004 r. Rozważania ograniczono do grupy wybranych przez autora na podstawie analizy literatury przedmiotu niemonetarnych wskaźników wykluczenia społecznego, w których znalazły się również wskaźniki z Laeken. Dane o wartościach wskaźników zaczerpnięto z bazy Eurostat dla 2020 r. W badaniu wykorzystano metodę wielowymiarowej analizy porównawczej wzorca rozwoju Hellwiga. Wykazano, iż na tle wybranych do analizy państw najkorzystniejszą sytuacją pod względem wykluczenia społecznego, rozumianego przez pryzmat niemonetarnych wskaźników, cechowały się Czechy, Słowenia oraz Polska.

Słowa kluczowe: wykluczenie społeczne, zrównoważony rozwój, wielowymiarowa analiza porównawcza. 